\title{
Ранний славяноболгарский вклад в венгерский язык
}

\author{
ANDRÁS ZOLTÁN \\ ELTE Szláv és Balti Filológiai Intézet, H-1088 Budapest, Múzeum krt. 4/D. \\ Institute of Slavonic and Baltic Philology, Faculty of Humanities, Eötvös Loránd University \\ E-mail: zoltand@caesar.elte.hu
}

(Received: 15 March 2018; accepted: 22 May 2018)

\begin{abstract}
The Slavic substratum of the Hungarian language was not uniform in a dialectical sense. Among the late Slavic dialects of the 9th century, in addition to the so-called Pannonian Slavic, also a dialect of Bulgarian character was represented not only in the southeastern peripheral areas, as it had previously been suspected, but also in some central parts of the present-day Hungarian language area. In this paper, the author provides language material for the localization of these former dialects.
\end{abstract}

Keywords: Slavic-Hungarian language contacts, the oldest Hungarian borrowings from Slavic, Slavic dialects, Old Bulgarian dialects

\section{Памяти Евгения Арнольдовича Хелимского}

1. Самый древний пласт славянских заимствований венгерского языка представляет интерес как для истории венгерского, так и славянских языков. Эрудированный и в области уралистики, и в области славистики лингвист Евгений Арнольдович Хелимский (1950-2007) с полным правом планировал создать две монографии на данную тему. В одной из них («Исследование венгерско-славянских языковых контактов раннего времени») рассматривались бы славянские заимствования с точки зрения венгерского языка, а в другой («Язык паннонских славян и его субстратное влияние на венгерский язык») венгерский материал был бы использован для реконструкции. К сожалению, вследствие преждевременной смерти автора этим трудам не дано было осуществиться; о них можно судить по их планам и некоторым материалам, еще при жизни переданным автором М. Стаховскому, который и издал их после смерти Е. А. Хелимского (SтAсHOWsкi 2009). Концепция Е. А. Хелимского, однако, стала известна научному сообществу уже раньше, при жизни исследователя, прежде всего благодаря двум крупным докладам на Международных съездах славистов (ХЕлимский 1988, ХЕлимский 1993) и некоторым другим публикациям, вошедшим впоследствии в собрание его трудов (ХЕлимский 2000; из его работ, не вошедших в данный том, но релевантных для нашей темы, см. еще HeLimski 1992, HeLimski 2003).

В венгерской славистике начиная с Я. Мелиха преобладает взгляд на славянские заимствования, в том числе и на самые древние, как на адстратные, причем этот адстрат рассматривался как параллельное влияние многих славянских языков одновременно, прежде всего тех, которые были расположены 
вокруг венгерской языковой территории, в непосредственном соседстве с Карпатским бассейном, занятым венграми в конце IX в. (MeLICH 1910). В общих своих высказываниях к этой точке зрения присоединился также И. Книежа (KNIEZSA 1942b: 178), и этот взгляд господствует и в современных пособиях по истории венгерского языка (см., например, BÁRCZI 1966: 116, KISS 1993: 111, ZSILINSZKY 2003: 382, GERSTNER 2018: 253-255). Венгерские исследователи, разумеется, отдавали себе отчет в том, что в ранний период (да иногда и в более новое время) в большинстве случаев нельзя определить, из какого славянского языка были взяты отдельные славизмы (MELICH 1910: 31, KNIEZSA 1942b: 178). Единственным исключением в довоенной венгерской славистике был в этом отношении Й. Балашша, который огромное количество славянских заимствований объяснял не маргинальными славяно-венгерскими языковыми контактами, а ассимиляцией венграми показательного числа населения, говорившего на славянском языке (BALASSA 1937: 46, BALASSA 1943: 20), т. е. у исследователя уже появляется мысль о том, что древние славизмы венгерского языка это не адстрат, а субстрат, языковое наследие от тех славян, которые были ассимилированы венграми после того, как они поселились в Карпатском бассейне. В пользу такого объяснения говорит и факт, что большинство древних славизмов венгерского языка - это не диалектизмы, а слова общевенгерского распространения и их история также не обнаруживает следов того, что они раньше могли быть диалектизмами; следовательно необходимо принять, что такие слова большей частью были заимствованы в центральных областях Карпатского бассейна, а не где-то на его окраинах. Позже о славянском субстрате венгерского языка в связи с топонимией вспомнил попутно и Л. Бенкё (см. ВЕNкÖ 1997: 170). В пользу субстратного характера древнего пласта венгерских славизмов наиболее определенно высказался, однако, Е. А. Хелимский, впервые в упомянутом докладе на софийском съезде (Хелимский 1988). В отличие от классиков венгерской славистики, которые считали, что предки венгров никогда не встречались с носителями праславянского языка, Е. А. Хелимский - вслед за Н. С. Трубецким (1925) и Н. Н. Дурново (1932) исходил из того, что о большинстве древних славизмов венгерского языка нельзя сказать, из какого конкретного славянского языка они были заимствованы просто потому, что отдельные славянские языки в IX-XI вв. еще не были сформированы, и венгры поселились в Карпатском бассейне среди славян, говоривших на позднепраславянских диалектах. Эту весьма разумную и очень правдоподобную гипотезу о характере начального этапа славяно-венгерских языковых контактов Е. А. Хелимский продолжал разрабатывать и в 1990-х гг. (ср. ХЕлимский 1993), но его взгляды не вызвали особого отклика в венгерской науке (ср., однако, ZoLTÁN 1996, ZoLTÁN 2013, ZoLTÁN 2017). Для этого было бы уже давно пора порвать с традиционным представлением о хронологии праславянского языка, концом которого ведущие венгерские слависты считали V в. (ср. KNIEZSA 1942a: 7-31, KNIEZSA 1942b: 178; так еще и KIss 1994: 361). Если согласиться с Н. С. Трубецким в том, что последним общеславянским изменением было падение редуцированных (TRUBETZKOY 1925: 
93-94, ТруьЕцкой 1927: 55-56), то не стоит искать отдельные славянские языки в современном смысле в Карпатском бассейне и на его окраинах до XIII в. Отрадно все-таки, что если не в собственно лингвистической литературе, но в работах по этнологии, а именно в связи с реконструкцией этнических процессов X в. в Карпатском бассейне, субстратный характер древних славизмов венгерского языка неизбежно получает признание как самое естественное объяснение массового характера заимствований в определенных тематических группах (например, в области сельскохозяйственной лексики, cp. NAGY 2017).

2. При всей убедительной силе новаторского подхода Е. А. Хелимского к проблеме древних славизмов венгерского языка, я счел необходимым внести некоторые коррективы в картину, которая вырисовывается на основе его работ на данную тему. Мне думается, что стоит вернуться к этому вопросу хотя бы для того, чтобы избежать некоторых недоразумений.

Итак, говоря о славянском диалекте Паннонии, Е. А. Хелимский склонен видеть в нем относительно единый диалект, сочетающий некоторые западнославянские черты - *ort-, *olt- > *ot-, *lot-, ср. венг. rab 'раб, заключенный', венг. ladik 'лодка'; сохранение праславянского сочетания * $d l$, откуда в венгерском $l l$, cp. венг. villa 'вилы, вилка' - с южнославянскими, точнее с теми из них, которые совпадают с хорватскими и /или словенскими континуантами праславянских сочетаний * $t j$ и * $d j$ : венг. теgye 'медье (административная единица)', венг. ragya 'язвина (на коже)', венг. parittya 'праща', венг. lencse 'чечевица' (ХЕлимский 1988: 357-359, cp. Zoltán 2013: 211-212).

Тем не менее, встречаются и другие рефлексы, которые имеют однозначно южнославянский характер. В части случаев праславянское сочетание * $d l$ дало $l$, которое в венгерском отражается не как $l l(<* d l)$, а как $l$ или $l y$ : венг. zab(o)la 'грызло, удила' < южносл. *zobalo < прасл. *zobadlo; венг. nyoszolya 'ложе' < южносл. *nosilo < прасл. *nosidlo. Из праславянского сочетания *ort- в начале слова иногда получилось rat-, как и в южнославянских диалектах, а гласный $a$ в этих сочетаниях в венгерском отражается как $\dot{a}[\bar{a}]$ : венг. диал. rásza 'рассада' < южносл. *rasadb < *raz-sadb < прасл. *orz-sadb; венг. устар. rászt 'увеличение селезенки' < южносл. *rastb < прасл. *orstb. Рефлексами праславянских сочетаний * $t j$, *dj в этом диалекте выступают $\check{s} t$, $\check{z} d$ как в древнеболгарском и в современном болгарском: венг. nyüst 'ремизка; нитченка' < др.-болг. ništi (мн. ч.; ср. Срезн. 2: 457 s. v. ничь) < прасл. *nitji; венг. mostoha 'мачеха' < др.-болг. maštecha (SJS 2: 198) < прасл. *matjecha; венг. mezsgye 'межа' < др.-болг. mеžda < прасл. *medja; венг. rozsda 'ржавчина' < др.-болг. rъžda< прасл. *rъdja. Эти особенности, вместе взятые, объясняются естественнее всего на основе болгарского (ср. ZoLTÁN 2013: 212, ZoLTÁN 2017: 227). Не совсем понятно, почему некоторые исследователи причисление изменения $* d l>l$ к характерным чертам болгарского типа наречий считают антиисторичным; объяснение вроде «изменение $d l, t l>l$ прошло, скорее всего, значительно раньше начала существования славяно-болгарского типа» (BRAXATORIS-ONDREJČ́́ 2017: 58 и прим. 10) не противоречит тому, что 
в X в. в славянских прототипах венгерских слов типа zab(o)la, nyoszolya звучало $l$, а не $d l$, что разумеется, характеризовало не один южнославянский диалект, а большинство их.

До обоснования венгров в Карпатском бассейне юго-восточные окраины средневековой Венгрии находились в сфере влияния болгарского государства, поэтому исследователи склонны предполагать, что в Трансильвании и в прилегающих к ней областях были распространены славянские диалекты именно болгарского типа. Но принадлежность к болгарскому государству, естественно, необязательно сочеталась с каким-либо диалектом. Если и принять то, что на самом деле в этих областях жили носители таких диалектов, и слова типа венг. mostoha 'мачеха', mezsgye 'межа', rozsda 'ржавчина' с явно болгарскими $\check{s} t, \check{z} d$ вошли в венгерский язык именно из языка этих славян, то остается непонятным, как эти слова могли стать общевенгерскими, а не только (хотя бы на первых порах) элементами венгерских периферийных говоров. Следует учитывать, что во время переселения венгров в Карпатский бассейн славянские диалекты болгарского типа должны были существовать не только на окраинах, но и в центральных областях будущей Венгрии. На географическое положение говоров болгарского типа в Карпатском бассейне могут указывать географические названия с элементом pest, мотивированным значением 'пещера'. Сюда относится прежде всего топоним Pest - ныне левобережная часть Будапешта, но раньше это название обозначало правобережную, холмистую часть сегодняшней столицы (современную Буду), богатую пещерами. Данное слово в венгерском языке является не только фонетическим, но и семантическим болгаризмом. Рефлексы праславянского *pektb существуют, правда, во всех славянских языках, но только в значении 'печь', значение 'пещера' имеется только в болгарском: пещ 'печь; пещера', ср. также в древнеболгарском: peštb '1. печь; 2. пещера' (SJS 3: 32, СтСл 1994: 445). Дальше сюда относятся сложные топонимы типа Pestkö, Köpest (kö 'камень, скала' + pest 'пещера', т. е. 'гора с пещерой'), старые Pest pataka ('ручей, вытекающий из пещеры') и munihpest ('пещера отшельника'). Эти названия распространены в широкой полосе от Будайских гор до окрестностей г. Мишкольц, а также несколько севернее, от реки Ваг до северных окраин комитата Боршод по обеим сторонам современной словацко-венгерской государственной границы (см. KNIEZSA 1963, DéNES 1997, DÉNES 2009; cp. ZOLTÁN 2013: 213 , HOFFMANN-TóTH 2016: 290-292). На географическое расположение этого славянского диалекта болгарского типа может пролить некий свет также диалектизм rásza 'рассада', который известен на восточном отрезке современной границы словацкой и венгерской языковой территории (ÚMTSz 4: 675), причем слово в словацком не засвидетельствовано.

3. В массе старых славянских заимствований венгерского языка значительное место занимают элементы христианской терминологии. Следует согласиться с Е. А. Хелимским в том, что большинство относящихся сюда слов тоже носят субстратный характер и являются нейтральными в отношении к принадлежности носителей славянского языка-источника к христианству 
западного или восточного обряда (ХЕлимский 1993). В меньшем количестве, но все-таки имеются в венгерском языке и христианские термины, которые не могут быть объяснены как происходящие из языка паннонских славян. При этом очевидна отсылка к Македонии как к области их первичного распространения.

Несмотря на то, что окончательную победу в Венгрии одержала западная миссия, в результате которой при Гезе и Стефане I венгерское христианство прочно вошло в сферу влияния римской церкви, венгерская христианская терминология сохраняет доныне ряд важных терминов, восходящих к терминам, бытующим в языках славян, принадлежащих к православной церкви, и неизвестным славянам-католикам.

Древность этого православного славянского слоя венгерской христианской терминологии не вызывает сомнений: эти слова должны были быть прочно усвоены как элементы венгерской лексики до начала западной миссии, так как в противном случае они были бы заменены словами, обычными в языках славян-католиков. Таким образом, этот слой славянских заимствований в венгерском языке с уверенностью можно отнести к Х веку.

Дискуссионными являются вопросы, связанные с конкретными путями проникновения этих заимствований в венгерский язык, т. е. культурно-исторический фон заимствования этих терминов, а также определение непосредственного источника заимствования. Иштван Книежа в своем этимологическом словаре славянских элементов венгерской лексики ограничивался обычно констатацией, что такие слова были заимствованы венгерским языком из языка одного из православных славянских народов, указывая на соответствующие формы в старославянском, в церковнославянском русской и сербской редакций, в русском, украинском, болгарском и сербском языках; только в случае венг. zarándok 'паломник' (ср. ст.-сл. страньникъ; рус.-цсл. страньникъ, рус. странник из цсл.) ученый высказался определенно в пользу заимствования венгерского слова из древнеболгарского (KNIEZSA 1955: 568-569). И. Книежа при этом категорически отрицал возможность какого-либо воздействия старославянского книжного языка на венгерскую лексику (см. KNIEZSA 1955: 121, 175). Однако, учитывая сказанное о хронологии этих слов в венгерском, напрашивается вывод о том, что также в случае других относящихся сюда слов самым вероятным передатчиком был древнеболгарский, поскольку во время крещения Руси (988 г.) в Венгрии уже развернулась западная миссия, а в Х в. с сербами венгры еще не имели непосредственных контактов. Поэтому Оскар Ашбот в свое время рассматривал все эти слова наравне с другими древнеболгарскими заимствованиями венгерского языка как результат болгарско-венгерских пограничных языковых контактов (см. AsBóтн 1983, Алво́тн 1907). Янош Мелих в свою очередь подчеркивал принадлежность данных слов к церковной терминологии н возводил их к старославянскому книжному языку (древнецерковнославянскому в его терминологии), не обосновав, однако, в каких конкретных обстоятельствах такое влияние могло иметь место (МеLICH 1903-1905). 
Таким образом, в венгерском языке имеется ряд древних христианских терминов, которые по хронологии и по культурно-историческим соображениям могут быть только древнеболгарскими по происхождению, но они не могут быть заимствованиями из старославянского книжного языка, так как старославянский литургический язык перестал функционировать в Паннонии до пришествия венгров. Как преодолеть это противоречие?

Древний православный пласт венгерской христианской терминологии естественнее всего связывать с византийской миссией к венграм в середине $\mathrm{X}$ века, как это и делалось в работах венгерского историка Дьёрдя Дьёрфи (GYÖRFFY 1983). Основным источником сведений об этой миссии является хроника Иоанна Скилицы (вторая половина ХІ в.), согласно которой константинопольский патриарх Феофилакт (933-956 гг.) в связи с крещением венгерского вождя Дьюлы в Константинополе (это событие датируется 953 г., см. GYÖRFFY 1983: 682-683) назначил епископом Венгрии монаха Иерофея, который, прибыв к венграм, обратил многих венгров в христианство (MORAVCSIK 1984: 85). Развивая мысль Дьёрдя Дьёрфи, можно сделать вывод, что православный слой венгерской христианской терминологии имеет древнеболгарский характер не потому, что византийская миссия имела успех прежде всего в юго-восточной Венгрии (на территории вождя Дьюлы), т. е. на территории, которая раньше (до пришествия венгров в 895 г.) входила в состав Болгарии и на которой можно предположить проживание болгарского (как протоболгарского, т. е. тюркского, так и славяноболгарского) населения во время вторжения венгров в Карпатский бассейн, а потому, что греческие миссионеры, прибывшие к венграм в сопровождении епископа Иерофея ок. 953 г., распространяли христианскую веру среди венгров при помощи древнеболгарского (разговорного) языка, которым владели греческие миссионеры (или часть их), т. е. в качестве языка-посредника между греками и венграми выступал славянский язык. В Византии нетрудно было найти священников, говоривших на славянском диалекте болгарского типа. Таких билингвов можно было легче всего отыскать на территориях со смешанным - греческим и славянским населением, не вошедших в состав 1-го Болгарского царства, а оставшихся в пределах Византийской империи. Эти билингвы могли вообще не знать славянский литургический язык, созданный своими соотечественниками - Константином-Кириллом и Мефодием - 90 лет тому назад, могли быть совершенно не знакомы с древнеболгарской грамотой, но они говорили на том славянском диалекте, который был положен в основу этого литургического языка Константином-Кириллом и Мефодием, т. е. они были знакомы с разговорным субстратом первого литературного языка славян. В подтверждение сказанного мне хотелось бы обратить внимание на несколько слов славянского происхождения, входящих доныне или входивших раньше в венгерскую христианскую терминологию, которые могут считаться заимствованными только из языков православных славян Македонии (ср. ZoLTÁN 1986, ZoLtÁN 2015).

Венг. karácsony 'рождество', засвидетельствованное в памятниках венгерского языка начиная с 1211 г., восходит к славянскому источнику, который 
известен в древнерусском - корочюнъ 'пост перед рождеством' (ДРС 7: 344), в русских диалектах - карачун 'солноворот, день 12 декабря, Спирдоньев день' (Даль 2: 91), а также в болгарских диалектах - крачун 'народен празник по летен или зимен кръговрат на слънцето: някъде 8-21 юни, а другаде Бъдни вечер' (БЕР 2: 726); исходным значением предполагаемого праславянского *korčunъ могло быть скорее всего 'зимний солнцеворот' (из древнеалбанского karcun 'пень, сжигаемый в языческий праздник зимнего солнцеворота', см. С̧ABEJ 1961). Знаменательно, что славянское крачун исключительно в значении 'рождество Христово', т. е. в значении, точно соответствующем значению венгерского слова karácsony, засвидетельствовано как раз в македонских диалектах на территории Греции и Албании (BalkMac 9 и карта № 16). Не может быть случайным, что в румынском сrăciun обозначает также 'рождество Христово'. Поскольку венгерская христианская терминология не испытывала никакого влияния со стороны румынской (KNIEZSA 1955: 254), венгерское слово не может быть заимствованным из румынского; но поскольку румынская церковь в средневековье подчинялась охридскому епископству (KNIEZSA 1943: 32), вполне возможно, что венг. karácsony и рум. crăciun заимствованы параллельно из того же югозападноболгарского (македонского) источника.

Bенг. hála ‘благодарность' в принципе может восходить к любому славянскому языку, в котором праславянское chvala имеет наряду со своим общеславянским значением также значение 'благодарность', т. е. к словенскому, сербохорватскому или древнеболгарскому. Венг. hála, однако, входит в устойчивое сочетание hálát ad 'благодарить’ (букв. «хвалу [= ‘благодарность’] да[ва]ть»), которое в венгерском употребляется доныне почти исключительно только в религиозном контексте (в других контекстах употребляется глагол köszön 'благодарить'). Этот фразеологизм из современных южнославянских языков имеет точные параллели только в языках южных славян, давно соседящих с венграми - в кайкавско-хорватском и словенском, в которых соответствующий фразеологизм hvalu dati является скорее всего калькой с венгерского (KNIEZSA 1955: 209-210). Венгерский фразеологизм hálát ad ‘благодарить’ име-

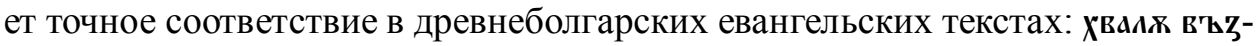
дdати 'благодарить'. Учитывая древность (в памятниках отмечается с XIV в., cм. TESz 2: 31, EWUng 1: 516) и явно церковное происхождение фразеологизма hálát ad в венгерском (вопреки мнению Иштвана Книежи, ср. KNIEZSA 1955:210), а также несоответствие с латинским выражением gracias ago, встречающимся в латинском переводе Нового завета в соответствующих местах, я склонен видеть в венгерском выражении hálát ad полукальку древнеболгарского выражения Хвдлж въъдағати, а в существительном hála-заимствование из древнеболгарского хвыл ‘благодарность' (вопреки мнению составителей современных этимологических словарей венгерского языка, которые венг. hála возводят к сербохорватскому или словенскому, cp. TESz 2: 31, EWUng 1: 516).

Показательно в этом отношении и происхождение венгерского слова pit$v a r$ 'сени', которое в настоящее время является термином народной архитектуры, но впервые засвидетельствовано в явно религиозном контексте pulkul 
pituara 'преддверие ада' (ок. 1300 г., см. TESz 3: 217, EWUng 2: 1169), что однозначно указывает на то, что это ныне народное венгерское слово первоначально входило в церковную терминологию (ср. KNIEZSA 1955: 426). Венг. pitvar было заимствовано из славянского pritvorz, которое принадлежало несомненно к разговорному субстрату старославянского книжного языка, так как притворъ в древнеболгарском представляет собой народно-этимологиче-

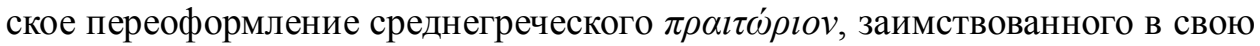
очередь из латинского praetorium (TESz 3: 217-218, EWUng 2: 1169-1170). Как известно, наряду с формой пюитворъ в древнеболгарских памятниках засвидетельствован и вариант пюєтөљт (СтСл 1994: 498-499) из двух вариантов именно притворт, к которому и восходит венг. pitvar, является несомненно народным, изустным заимствованием из среднегреческого.

Приведенные примеры указывают на то, что православный слой венгерской христианской терминологии был заимствован из того же славянского диалекта, который лег в основу старославянского книжного языка, созданного солунскими братьями Констаитином-Кириллом и Мефодием во второй половине IX в. Таким образом, мне представляется, что этот древний слой венгерской лексики не имеет, правда, непосредственного отношения к кирилло-мефодиевскому книжному языку (такому предположению противоречат исторические факты), но имеет прямое отношение к диалектной базе этого книжного языка (такое предположение подтверждается как историческими, так и лингвистическими показаниями).

\section{Литература}

БЕР = Български етимологичен речник. Т. 1-8. София, 1971-2017.

ДАль = ДАль В. И. Толковый словарь живаго великорускаго языка. Т. 1-4. СанктьПетербургъ-Москва, 1880-1882.

ДРС = Словарь русского языка XI-XVII вв. Вып. 1-28. Москва, 1975-2008.

Дурново 1932 = Дурново Н. Н. К вопросу о распадении общеславянского языка. In: Sborník prací I. Sjezdu slovanských filologův Praze, 1929. Svazek 2. Přednášky. Praha, 1932. 514-526. [Переиздано в кн.: Дурново Н. Н. Избранные работы по истории русского языка. Москва, 2000. 624-637.]

Срезн. = СРЕзнЕвскІй И. И. Материаль для словаря древне-русскаго языка по письменнымъ памятникамъ. Т. 1-3. Санктъ-Петербургъ, 1893-1903.

СтСл 1994 = ЦЕйтлин Р. М., ВЕЧЕРКА В., БЛАГОВА Э. (ред.) Старославянский словарь (по рукописям $X-X I$ веков). Москва, 1994.

ТрУБецКОй 1927 = ТруБецкой Н. С. К проблеме русского самопознания. Paris, 1927. [Переиздано в кн.: ТруьЕцКой 1995: 162-210.]

ТруБецКОЙ 1987 = ТруБЕцКой Н. С. Избранные труды по филологии. Москва, 1987.

ТруБЕцКОй 1995 = ТрУБецКОй Н. С. История, культура, язык. Москва, 1995.

ХЕлимский 1988 = Хелимский Е. А. Венгерский язык как источник для праславянской реконструкции и реконструкции славянского языка Паннонии. В кн.: Славянское языкознание. Х Международный съезд славистов. Доклады советской делегации. Москва, 1988. 347-368. [Переиздано в кн.: ХЕлимский 2000: 416-432.] 
ХЕлимский 1993 = ХЕлимский Е. А. Ранняя славянская христианская терминология в венгерском языке. В кн.: Славянское языкознание. ХІ Международный съезд славистов. Доклады российской делегащии. Москва, 1993. 46-64. [Переиздано в кн.: ХЕлимСКий 2000: 436-451.]

ХЕЛИМский $2000=$ ХЕЛИмский Е. А. Компаративистика, уралистика. Лекции и статьи. Москва, 2000.

Asво́тн 1907 = AsвÓTH Oszkár: Szláv jövevényszavaink 1. Bevezetés és a különbözö rétegek kérdése. Budapest, 1907.

AsвóTH 1983 = AsвóTH Oszkár: A szláv szók a magyar nyelvben. Budapest, 1983.

BALASSA 1937 = BALASSA József: A magyar nyelv életrajza. Budapest, 1937.

BALASSA 1943 = BALASSA József: A magyar nyelv könyve. Budapest, 1943.

BalkMac = Koneski B., VidOESKI B., JASAR-NASTEVA O. Distribution des balkanismes en macédonien. Skopje, 1966.

BÁrCZI 1966 = BÁrCzI Géza: A magyar nyelv életrajza. Budapest, 1966.

BENKÖ 1997 = BENKÖ Loránd: A honfoglaló magyarság nyelvi viszonyai és ami ezekből következik. In: KovÁcs László, VEszPrémy László (szerk.): Honfoglalás és nyelvészet. Budapest, 1997. 163-176.

BRAXATORIS-ONDREJČ́́K 2017 = BRAXATORIS Martin, ONDREJČíK Michal: Гетерогенность праславянской основы словацкого языка как последствие склавинско-аварского воздействия. В кн.: КРАСНЫХ В. В., Изотов А. И. Язык, сознание, коммуникация. Сборник статей к юбилею профессора Н. Е. Ананьевой. Москва, 2017. 46-67.

ÇABEJ 1961 = ÇABEJ Eqrem: Crăciun. Studii şi Cercetări Lingvistice 12 (1961): 313-317.

DÉNES 1997 = DÉNES György: A Munuhpest sziklája és a pest köznév jelentése hegyek, sziklák nevében. In: Gergely Piroska, HAJdú Mihály (szerk.): Az V. magyar névtudományi konferencia elöadásai 1. Budapest-Miskolc, 1997. 284-288.

DÉNES 2009 = DÉNES György: Pest pataka. Névtani Értesítő 31 (2009): 105-111.

EWUng = BENKÖ Loránd (Hrsg.): Etymologisches Wörterbuch des Ungarischen. Bd. 1-3. Budapest, 1993-1997.

GERSTNER 2018 = GERSTNER Károly: Szókészlettan. In: Kiss Jenő, PuszTAI Ferenc (szerk.): A magyar nyelvtörténet kézikönyve. Budapest, 2018. 249-270.

GYÖRFFY 1983 = GYÖRFFY György: István király és müve. Budapest, 1983.

HELIMSKI 1992 = HELIMSKI Eugen: Slavic/Latin / German stress and Hungarian vowel harmony. In: Finnisch-ugrische Sprachen zwischen dem germanischen und dem slavischen Sprachraum. Amsterdam-Atlanta, 1992. 45-54.

Helimski 2003 = Helimski Eugen: Bécs und Pécs vor dem Hintergrund der ungarischen Vertretung der slawischen Nasalvokale. In: BAKRó-NAGY Marianne, RÉDEI Károly (szerk.): Ünnepi könyv Honti László tiszteletére. Budapest, 2003. 181-193.

HofFMANN-TóTH 2016 = HofFMANN István, TóTH Valéria: A nyelvi és etnikai rekonstrukció kérdései a 11. századi Kárpát-medencében. Századok 150 (2016): 257-318.

KISS 1993 = KISS Jenő: A magyar nyelv. In: KósA László (szerk.): A magyarságtudomány kézikönyve. Budapest, 1993. 77-161.

KIss 1994 = KISS Lajos: Néhány szlavisztikai müszóról (ősszláv nyelv, ószláv nyelv, egyházi szláv nyelv, óorosz nyelv). Magyar Nyelv 90 (1994): 361-363.

KNIEZSA 1942a = KNIEZSA István: A szlávok őstörténete. In: SzEKFŰ Gyula (szerk.): A magyarság és a szlávok. Budapest, 1942. 7-40.

KNIEZSA 1942b = KNIEZSA István: Magyar-szláv nyelvi érintkezések. In: SzEKFÜ Gyula (szerk.): A magyarság és a szlávok. Budapest, 1942. 168-188. 
KNIEZSA 1943 = KNIEZSA István: Siebenbürgen zur Zeit der Landnahme und die Ansiedlung des Ungarntums. In: MÁLyuSz Elemér (Hrsg.): Siebenbürgen und seine Völker. Budapest-Leipzig-Milano, 1943. 19-35.

KNIEZSA 1955 = KNIEZSA István: A magyar nyelv szláv jövevényszavai I/1-2. Budapest, 1955.

KNIEZSA 1963 = KNIEZSA István: Charakteristik der slawischen Ortsnamen in Ungarn. Studia Slavica Hung. 9 (1963): 27-44.

Melich 1903-1905 = Melich János: Szláv jövevényszavaink I/1-2. Budapest, 1903-1905.

Melich 1910 = Melich János: Nyelvünk szláv jövevényei. (A Magyar Nyelvtudományi Társaság Kiadványai 13.) Budapest, 1910.

MorAVCSIK 1984 = MorAVCSIK Gyula: Az Árpád-kori magyar történet bizánci forrásai / Fontes Byzantinae historiae Hungaricae aevo ducum et regum ex stirpe Árpád descendentium. Budapest, 1984.

NAGY 2017 = NAGY Iván: Kísérlet a 10. századi Kárpát-medence etnikai rekonstrukciójára. In: SudÁR Balázs (szerk.): Dentumoger I. Tanulmányok a korai magyar történelemröl. Budapest, 2017. 357-398.

SJS = KURZ Josef, HAUPTOVÁ Zoé (red.): Slovník jazyka staroslověnského / Lexicon linguae palaeoslovenicae. T. 1-4. Praha, 1966-1997.

STACHOWSKI 2009 = STACHOWSKI Marek: Eugen Helimskis Materialien zur Erforschung der ältesten slawisch-ungarischen Sprachkontakte. Studia Etymologica Cracoviensia 14 (2009): 35-107.

TESz = BENKÖ Loránd (szerk.): A magyar nyelv történeti-etimológiai szótára 1-4. Budapest, 1967-1984.

TRUBETZKOY 1925 = TRUBETZKOY N. S. Einiges über die russische Lautentwicklung und die Auflösung der gemeinrussischen Spracheinheit. Zeitschrift für Slavische Philologie 1 (1925): 287-319. [Переиздано в кн.: ТRUBETZKOY 1988: 93-125. Русский перевод: ТРУБЕцКОЙ 1987: 143-167.]

TrubetzKoy 1988 = TRUBETZKOY N. S. Opera slavica minora linguistica. Wien, 1988.

ÚMTSz = B. LÖRINCZY Éva (szerk.): Új magyar tájszótár 1-5. Budapest, 1979-2010.

ZoLTÁn 1986 = ЗолTAH A. О происхождении православного славянского слоя в венгерской христианской терминологии. Съпоставително езикознание 1986/4: 5-9.

ZOLTÁN 1996 = ZoLTÁN András: A magyar-szláv érintkezések kezdetei és fázisai. Életünk 34 (1996): 634-648.

ZOLTÁN 2013 = ZoLTÁN András: Славянские диалекты Карпатского бассейна во время прихода венгров (IX в.). Studia Slavica Hung. 58 (2013): 209-218.

Zoltán 2015 = ZoltÁn András: Византийская миссия у венгров в Х в.: Вопрос о славянском языковом посредничестве. In: Tаніаоs Anthony-Emil (ed.): Cyril and Methodius. Byzantium and the World of the Slavs. Thessaloniki, 2015. 658-663.

ZoLTÁN 2017 = ZoLTÁN András: Ślady dawnych gwar typu bułgarskiego w północnowschodnich Węgrzech. LingVaria 2017/1: 223-230. 